\title{
Influence of Environmental Conditions and Gibberellic Acid on Germination of Curry Leaf (Murraya koenigii (L.) Spreng.)
}

\author{
A. D. Ashok*, K. Kayalvizhi and J. Ravivarman \\ Institute of Agriculture, Tamil Nadu Agricultural University, Kumulur-621712, India \\ *Corresponding author
}

\section{A B S T R A C T}

\section{Keywords}

Curry leaf, GA3, seed germination and environmental conditions

Article Info

Accepted:

12 March 2021

Available Online:

10 April 2021
Curry leaf extensively cultivated for its aromatic leaves throughout India. It is used in many of Ayurvedic and Yunani prescriptions. Its leaves, roots and bark are credited with tonic, stomachic and carminative properties. Currently, gibberellic acid $\left(\mathrm{GA}_{3}\right)$, an environmentally friendly bio-regulator is widely used to enhance the seed germination of different crops. A experiment was conducted to enhance the seed germination using gibberellic acid (200 ppm) under different environmental conditions (Shadenet house, poly house, mist chamber, open field and polybags) at Institute of Agriculture, Tamil Nadu Agricultural University, Kumulur during 2021. The following observations were recorded viz., germination percentage (\%), Number of leaves (Nos.), Shoot length $(\mathrm{cm})$ and Root length $(\mathrm{cm})$. The study was concluded that, mist chamber conditions promote seed germination very well than any other environmental conditions. Following mist chamber, shade net and polyhouse raised seedlings performed very well.

\section{Introduction}

Murraya koenigii (L.) Spreng., crop of Rutaceae family is commonly called as curry leaf known for its flavoured leaf condiment. It is used regularly in Indian cuisine. The leaves have a slightly pungent, bitter and feebly acidic taste, and they retain their flavour and other qualities even after drying. Curry leaf is also used in many of the Indian ayurvedic and unani prescriptions. It is being used both in fresh and dried forms.

The leaves are rich sources of protein $(6.1 \%)$, fat $(1 \%)$, Carbohydrate $(18.7 \%)$ and fibre (7.4\%) in addition to vitamins viz., carotene (as vitamin A, 12,600 IU), nicotinic acid (2.3 $\mathrm{mg}$ ) and vitamin $\mathrm{C}(4 \mathrm{mg})$ per $100 \mathrm{~g}$ of edible leaf. Leaves are rich source of calcium. But due to the presence of oxalic acid in high 
concentration, its nutritional availability is affected (Mamatha, 2001). The crop is usually propagated by seeds or suckers (Sivasubramaniam and Selvarani, 2012).

Since it produces recalcitrant seeds, the viability of seed, germination and survival percentage of the seed is not satisfactorily good.

Hence, a trust worthy methodology using current technology is needed for improving seed multiplication of curry leaf. With the aim of this, current experiment was aimed to find out the influence of various environmental conditions and germination promoting hormone in curry leaf seeds.

\section{Materials and Methods}

This experiment was conducted at Institute of Agriculture, Tamil Nadu Agricultural University, Kumulur, Trichy district of Tamilnadu.

This experiment was design as Split Plot method with main plot as Different environmental conditions (C) and sub-plot as Gibberellic acid (GA) treatment (G) with three replications. Main plot viz., Mist chamber (C1), Shadenet (C2), Polyhouse (C3), Raised bed under shade $(\mathrm{C} 4)$, Polybag nursery under shade (C5), and Open field condition (C6).

Sub-plot viz., Gibberellic acid - 200 ppm treated (G1) and Untreated (G2). Freshly extracted seeds are graded, sorted for viable seeds. Then seeds are implemented with GA3 treatments (sub-plot) and sown under various environmental conditions (Main- plot). The parameters such as Germination percentage (\%), Number of leaves, Shoot length of the seedling $(\mathrm{cm})$ and Root length of the seedlings (cm) are recorded 60 days after sowing. The statistical analyses were made with AGRES computer application.

\section{Results and Discussion}

Influence of environmental conditions in germination of curry leaf seedlings

Experimental results are recorded with highly significant values which are shown in table 1. Among the structures, mist chamber condition recorded significantly maximum germination percentage (97.67\%), number of leaves (24.01), shoot length $(9.34 \mathrm{~cm})$ and root length $(10.52 \mathrm{~cm})$. Germination percentage was recorded maximum next to the mist chamber under shade net $(95.33 \%)$ and polyhouse $(96.00 \%)$ which are on par with each other. Shade net and seedlings in polybag under shade recorded higher number of leaves (22.70 and 22.50) respectively which are on par with each other. Following the mist chamber, maximum shoot length $(7.56 \mathrm{~cm}$ and $7.35 \mathrm{~cm}$ ) was recorded in polyhouse and shade net; maximum root length was recorded under seedlings in polybag under shade $(9.16 \mathrm{~cm})$.

\section{Influence of Gibberellic acid}

Gibberellic acid treated seeds recorded maximum germination percentage $(96.05 \%)$, number of leaves (23.53), shoot length (6.67 $\mathrm{cm})$ and root length $(8.15 \mathrm{~cm})$ than untreated one.

Interaction effect of environmental conditions and gibberellic acid on germination of curry leaf seedlings

On analysing the interaction effect of protected structures and gibberellic acid on curry leaf seedlings, it is recorded that seedlings raised after treatment with gibberellic acid under mist chamber shows significant result in maximum germination percentage (98.67\%), number of leaves (28.02), shoot length $(10.7 \mathrm{~cm})$ and root length $(11.5 \mathrm{~cm})$ than any other treatment in the experiment. 
Table.1 Influence of Gibberellic acid and protected structures on germination of curry leaf

\begin{tabular}{|c|c|c|c|c|}
\hline & $\begin{array}{c}\text { Germination } \\
\text { percentage }(\%)\end{array}$ & $\begin{array}{l}\text { Number of } \\
\text { leaves(Nos.) }\end{array}$ & $\begin{array}{l}\text { Shoot length } \\
\text { (cm) }\end{array}$ & $\begin{array}{l}\text { Root length } \\
\text { (cm) }\end{array}$ \\
\hline \multicolumn{5}{|c|}{ Influence of protected structures (Main plot) } \\
\hline C1 - Mist chamber & 97.67 & 24.01 & 9.34 & 10.52 \\
\hline C2 - Shade net & 95.33 & 22.70 & 7.35 & 7.69 \\
\hline C3 - Polyhouse & 96.00 & 20.40 & 7.56 & 6.62 \\
\hline C4 - Raised bed under shade & 93.33 & 19.60 & 5.18 & 5.25 \\
\hline C5 - Polybag under shade & 91.99 & 22.50 & 5.1 & 9.16 \\
\hline C6 - Open field & 94.00 & 14.50 & 4.45 & 7.47 \\
\hline SED & 0.005 & 0.28 & 0.12 & 0.15 \\
\hline $\mathrm{CD}(0.05)$ & 0.013 & 0.62 & 0.27 & 0.34 \\
\hline \multicolumn{5}{|c|}{ Influence of GA3 (200 ppm) (Sub-Plot) } \\
\hline G1 - Treated & 96.05 & 23.53 & 6.67 & 8.15 \\
\hline G2 - Untreated & 93.39 & 17.70 & 6.33 & 7.42 \\
\hline SED & 0.003 & 0.16 & 0.08 & 0.03 \\
\hline $\mathrm{CD}(0.05)$ & 0.007 & 0.34 & 0.18 & 0.06 \\
\hline \multicolumn{5}{|c|}{ Interaction effect (Main plot x Sub plot) } \\
\hline C1G1 & 98.67 & 28.02 & 10.7 & 11.5 \\
\hline C1G2 & 96.67 & 20.00 & 7.98 & 9.54 \\
\hline C2G1 & 97.33 & 25.20 & 6.42 & 8.08 \\
\hline C2G2 & 93.33 & 20.20 & 8.28 & 7.30 \\
\hline C3G1 & 98.00 & 22.00 & 7.06 & 6.78 \\
\hline C3G2 & 94.00 & 18.80 & 8.06 & 6.46 \\
\hline C4G1 & 94.67 & 25.60 & 5.94 & 5.66 \\
\hline C4G2 & 92.00 & 13.60 & 4.42 & 4.84 \\
\hline C5G1 & 92.65 & 24.60 & 5.44 & 9.90 \\
\hline C5G2 & 91.33 & 20.40 & 4.76 & 8.42 \\
\hline C6G1 & 95.00 & 15.80 & 4.44 & 7.00 \\
\hline C6G2 & 93.00 & 13.20 & 4.46 & 7.94 \\
\hline SED & 0.01 & 0.39 & 0.18 & 0.16 \\
\hline $\mathrm{CD}(\mathbf{0 . 0 5})$ & 0.02 & 0.86 & 0.41 & 0.35 \\
\hline Grand mean & 94.72 & 20.62 & 6.5 & 7.79 \\
\hline CV(Main) & 0.01 & 2.33 & 3.23 & 3.36 \\
\hline CV(Sub/AXB) & 0.01 & 2.29 & 3.73 & 1.09 \\
\hline
\end{tabular}

Apart from mist chamber, seed treated and sown under polyhouse and shade net performed well. These results confined that the protected structures and gibberellic acid have influence over the seed germination and seedling growth in curry leaf. From the experiment, we observed that, mist chamber conditions promote seed germination very well than any other environmental conditions. Following mist chamber, shade net and polyhouse raised seedlings performed very well. Apart from this, seedlings under poly bag nursery given good result than raised bed nursery under shade and open field nursery. 
Masilamani and Dharmalingam (2001) reported in teak seeds that the fruit stones aged for 13 days under mist chamber at $100 \% \mathrm{RH}$ and $40^{\circ} \mathrm{C}$ showed $39 \%$ germination against $14 \%$ in the control after 11 days aging. This is in line with our experiment.

Upon the results we discussed, we can conclude that, relative humidity and shade influence the seed germination. In mist chamber, relative humidity and shade is comparatively higher than any other protected structures which results in better germination and seedling growth irrespective of $\mathrm{GA}_{3}$ treatment. Shade net promotes more shoot growth and leaves due to uniform shade. Polyhouse promotes good germination percentage and shoot length next to mist chamber. Reports by Singh et al., (1994) and Tehlan and Malik (2010) showed that plant height increases with effect of shading. Like findings of Jeeva and Sathiyamurthy (2001) in coriander supports our experimental findings.

$\mathrm{GA}_{3}$ helps in synthesis of á- amylase which converts the starch into simple sugars. These sugars provide energy that is required for various metabolic and physiological activities. During germination, GA induces the synthesis of hydrolytic enzymes, such as amylase and protease. These enzymes degrade the stored food reserves accumulated in the endosperm or embryo as the seed matured. This degradation of carbohydrate and storage protein provides nourishment and energy to support germination and seedling growth (Hota et al., 2018). Taiz and Zeiger, (2006) reported in cereals that Gibberellins $\left(\mathrm{GA}_{3}\right)$ activate the embryonic vegetative growth, weakens the endosperm layer that involves the embryo and restricts its growth, and mobilizes the energetic reserves from the endosperm.

$\mathrm{GA}_{3}$ treatment apart from improving germination also increased the subsequent growth of seedling. This may be attributed to cell multiplication and elongation of cells in the cambium tissue of internodal region by GA apparently activating the metabolic processes or nullifying the effect of an inhibitor on growth (Barton, 1958). Increase in plant height due to $\mathrm{GA}_{3}$ has also been reported by Ratan and Reddy (2004). Hota et al., (2018) reported that gibberellic acid increases germination, growth and survival of Jamun (Syzygium cumini L. Skeels). Babu et al., (2004) reported similar results in papaya. Apart from protected environment, polybag nursery under shade, with $\mathrm{GA}_{3}$ treatment has influence on seedlings growth particularly root growth.

Combined effect of environmental conditions and $\mathrm{GA}_{3}$ on seed germination and growth of curry leaf are better under protected conditions than under shade and open field condition. Further experiments may be conducted to find out environmental influence and other plant growth regulator effect on curry leaf seedling growth.

\section{References}

Babu K. D., Patel R. K., Singh A., Yadav D. S., Deka B. C. Seed germination, seedling growth and vigour of papaya under North East Indian condition. Acta Horticulturae. 2004; 851:299306.

Barton L. V. Growth response of physiologic dwarfs of Malus arnoldiana. To gibberellic acid. Contrib. Boyce Thompson Institute, 1958; 18:311-17.

Hota S N, Karna A K, Jain P K and Dakhad B. Effect of gibberellic acid on germination, growth and survival of jamun (Syzygium cumini L. Skeels). The Pharma Innovation Journal 2018; 7(8): 323-326.

Jeeva L, Sathiyamurthy V. A. Performance of gerbera under different growing 
structures. South Indian Hort., 2001; 51(1-6) : 66- 69.

Mamatha. Effect of nutrition and GA3 on yield of curry leaf (Murraya koenigii (L.) Spreng.), M.Sc. Thesis submitted to university of agricultural sciences, Dharwad, Karnataka, 2001.

Masilamani, P., \& Dharmalingam, C. Effect of accelerated aging on germination and seedling vigour of teak (Tectona grandis). Journal of Tropical Forest Science, 2001; 13(1), 93-98. Retrieved February 25, 2021, from http://www.jstor.org/stable/43582275

Ratan P B, Reddy Y N. Influence of gibberellic acid on custard apple (Annona squamosa L.) seed germination and subsequent seedling growth. Journal of Research ANGRAU. 2004; 32(2):93-95.

Singh D, Gill APS, Ramesh Kumar. Effect of summer shading on the plant growth and flower production of standard Carnation (Dianthus caryophyllus L.) cv. Espana under sub tropical condition of Punjab. J. Ornamental Horticulture, 1994; 2(1-2): 51-53.

Sivasubramaniam K. and Selvarani K. 2012. Studies on curry leaf (Murraya koenigii) seeds. Current Science, 103(8): 883 - 885

Taiz L, Zeiger E. Plant physiology. R, E. 3.ed. Porto Alegre: Artmed, 2006, 719

Tehlan SK and Malik TP. Influence of different shade intensities and varieties on leaf yield of coriander during summer. Abstract Book National Seminar on Recent Trends in Horticulture Crops- Issues and Strategies for Research and development. CCS Haryana Agricultural University. Hisar., 2010: 123.

\section{How to cite this article:}

Ashok, A. D., K. Kayalvizhi and Ravivarman, J. 2021. Influence of Environmental Conditions and Gibberellic Acid on Germination of Curry Leaf (Murraya koenigii (L.) Spreng.). Int.J.Curr.Microbiol.App.Sci. 10(04): 46-50. doi: https://doi.org/10.20546/ijcmas.2021.1004.005 